\title{
Pengelolaan Dana Wakaf oleh Alkhairaatdi Kota Palu
}

\author{
Triska Rosmala $^{1 *}$ Nursyamsu Nursyamsu ${ }^{2}$, Ahmad Haekal $^{3}$ \\ ${ }^{1}$ Jurusan Ekonomi Syariah, Fakultas Ekonomi dan Bisnis Islam, IAIN Palu \\ ${ }^{2}$ Jurusan Ekonomi Syariah, Fakultas Ekonomi dan Bisnis Islam, IAIN Palu \\ ${ }^{3}$ Jurusan Ekonomi Syariah, Fakultas Ekonomi dan Bisnis Islam, IAIN Palu
}

ABSTRAK

Alkhairaat merupakan salah satu penyelenggara pendidikan berbasis masyarakat yang melibatkan masyarakat dalam sistem pendidikan nasional melalui wakaf. Penelitian ini bertujuan untuk (a) mengetahui pengelolaan dana wakaf oleh Pengurus Besar Alkhairaat di Kota Palu; dan (b) mengetahui efisiensi pengelolaan dana wakaf oleh Pengurus Besar Alkhairaat di Kota Palu. Metode analisis yang digunakan pada penelitian ini adalah (a) metode deskripsi untuk menggambarkan manajemen keuangan pada objek penelitian; dan (b) metode analisis tabel untuk menghitung tingkat efisiensi pengelolaan dana wakaf dilihat dari sisi pengeluaran. Hasil penelitian menunjukkan bahwa (a) pengelolaan dana wakaf oleh Pengurus Besar Alkhairaat belum menunjukkan sebuah manajemen yang sempurna, di mana masih ada fungsi manajemen yang belum diterapkan dengan baik, yaitu perencanaan anggaran; dan (b) tingkat efisiensi pengelolaan dana wakaf oleh Pengurus Besar Alkhairaat pada tahun 2018 adalah 102\%, artinya pengelolaan dana wakaf tersebut belum efisien karena pengeluaran rata-rata per bulan (Rp138.746.358,33) lebih besar dari pemasukan rata-rata per bulan (Rp141.783.912,50).
INFORMASI

ARTIKEL

Kata kunci:

Dana wakaf, pengelolaan, Alkhairaat, manajeman wakaf. 


\section{PENDAHULUAN}

Sistem pendidikan nasional adalah keseluruhan komponen pendidikan yang saling terkait secara terpadu untukmencapai tujuan pendidikan nasional. ${ }^{1}$ Undang-undang Sistem Pendidikan Nasional menegaskan bahwa masyarakat berhak menyelenggarakan pendidikan berbasis masyarakat pada pendidikan formal dan nonformalsesuai dengan kekhasan agama, lingkungan sosial, dan budaya untuk kepentingan masyarakat. ${ }^{2}$

Biaya pendidikan merupakan salah satu komponen masukan instrumental yang sangat penting dalam penyelenggaraan sistem pendidikan nasional. Undang-undang Sistem Pendidikan Nasional menjelaskan bahwa dana penyelenggaraan pendidikan berbasis masyarakat dapat bersumber dari penyelenggara, masyarakat,Pemerintah, Pemerintah Daerah dan/atau sumber lain yang tidak bertentangan dengan peraturan perundang-undangan yang berlaku. ${ }^{3}$

Peran wakaf dalamsistem pendidikan nasional adalah sebagai bentuk sumbangsih masyarakat dalam mendanai penyelenggaraan pendidikan berbasis masyarakat, terutama penyelenggaraan

\footnotetext{
${ }^{1}$ Pasal 1 poin 3 Undang-undang Nomor 20 Tahun 2003 Tentang Sistem Pendidikan Nasional

2 Pasal 55 ayat 1 Undang-undang Nomor 20 Tahun 2003 Tentang Sistem Pendidikan Nasional

${ }^{3}$ Pasal 55 ayat 3 Undang-undang Nomor 20 Tahun 2003 Tentang Sistem Pendidikan Nasional
}

pendidikan swasta yang bersifat keagamaan. Peran wakaf tersebut sangat berpotensi menjamin keberlangsungan penyelenggaraan pendidikan swasta. Peran wakaf tersebut mewujudkan penyelenggaraan pendidikan oleh masyarakat, dari masyarakat, dan untuk masyarakat.

Alkhairaat merupakan salah satu penyelenggara pendidikan berbasis masyarakat yang melibatkan masyarakat dalam sistem pendidikan nasional melalui wakaf. Alkhairaat adalah warisan berharga dari masa lalu yang bertahan hingga hari ini berkat peran wakaf. Alkhairaat masih menjadi pusat penyelenggaraan pendidikan swasta yang bersifat keagamaan di Indonesia Bagian Timur, terutama di Kota Palu, Sulawesi Tengah.

\section{TINJAUAN PUSTAKA}

\subsection{Pengertian Wakaf}

Wakaf berasal dari Bahasa Arab waqf, bentuk kata benda dari kata kerja waqafa yang berarti menahan, mencegah, menghentikan, dan berdiam di tempat. ${ }^{4}$ Kata waqf juga semakna dengan habs, bentuk kata benda dari kata kerja habasa. Saat ini kata waqf lebih banyak digunakan di dunia, kecuali orang-orang Maroko yang masih

\footnotetext{
${ }^{4}$ A. Warson Munawwir, Kamus Al-Munawwir, (Surabaya: Pustaka Progressif, 2002), Cet. Ke25, h. 1576
} 
menggunakan istilah habs untuk menggantikan kata waqf sampai saat ini. ${ }^{5}$

Dr. Mundzir Qahf mendefinisikan wakaf dengan bahasa kontemporer, yaitu wakaf adalah menahan harta, baik selamanya atau sementara, untuk dimanfaatkan baik harta tersebut maupun hasilnya, secara berulang-ulang untuk suatu tujuan kemaslahatan umum dan khusus. ${ }^{6}$

Kompilasi Hukum Islam mendefinisikan wakaf sebagai perbuatan hukum seseorang atau kelompok orang atau badan hukum yang memisahkan sebagian dari benda miliknya dan melembagakannya untuk selama-lamanya guna kepentingan ibadat atau keperluan umum lainnya sesuai dengan ajaran agama Islam. $^{7}$ Kompilasi Hukum Islam menyatakan bahwa benda wakaf adalah segala benda, baik benda bergerak atau tidak bergerak yang memiliki daya tahan yang tidak hanya sekali pakai dan bernilai menurut ajaran Islam. ${ }^{8}$

Undang-undang Wakaf Nomor 41 Tahun 2004 mendefinisikan wakaf sebagai perbuatan hukum wakif untuk memisahkan dan/atau menyerahkan sebagian harta benda miliknya untuk dimanfaatkan selamanya atau untuk jangka waktu tertentu sesuai

\footnotetext{
5 Taufik Ridho, Panduan Wakaf Praktis, (Jakarta: Tabung Wakaf Indonesia, 2006), h. 3

${ }^{6}$ Abdurrahman, Masalah Perwakafan Tanah Milik dan Kedudukan Tanah Wakaf di Negara Kita, (Bandung: Citra Karya Bakti, 1994), h. 24

${ }^{7}$ Pasal 215 ayat 1 Kompilasi Hukum Islam

${ }^{8}$ Pasal 215 ayat 4 Kompilasi Hukum Islam
}

dengan kepentingannya guna keperluan ibadah dan/atau kesejahteraan umum menurut syariah. ${ }^{9}$

Undang-undang Wakaf Nomor 41 Tahun 2004 menyatakan bahwa harta benda wakaf terdiri diri dari benda tidak bergerak dan benda bergerak. Benda tidak bergerak meliputi hak atas tanah sesuai dengan ketentuan perundang-undangan yang berlaku, baik yang sudah maupun yang belum terdaftar; bangunan atau bagian bangunan yang berdiri di atas tanah; tanaman dan benda lain yang berkaitan dengan tanah; hak milik atas satuan rumah susun sesuai dengan ketentuan peraturan perundang-undangan yang berlaku; dan benda tidak bergerak lain sesuai dengan ketentuan syariah dan peraturan perundangundangan yang berlaku. Benda bergerak meliputi uang, logam mulia, surat berharga, kendaraan, hak atas kekayaan intelektual, hak sewa, dan benda bergerak lain sesuai dengan ketentuan syariah dan peraturan perundang-undangan yang berlaku. ${ }^{10}$

\subsection{Wakaf Produktif}

Wakaf produktif adalah harta benda wakaf yang bisa dipergunakan untuk kegiatan produksi dan menghasilkan keuntungan finansial, seperti tanah untuk

\footnotetext{
${ }^{9}$ Pasal 1 ayat 1 Undang-undang Nomor 41 Tahun 2004 tentang Wakaf

${ }^{10}$ Pasal 16 ayat 1-3 Undang-undang Nomor 41 Tahun 2004 tentang Wakaf
} 
digunakan bercocok tanam, mata air untuk dijual airnya, dan lain-lain. Wakaf produktifmeliputi bidang pertanian, perindustrian, perdagangan, jasa, dan lainlain yang manfaatnya bukan pada benda wakaf secara langsung, tetapi dari keuntungan yang dihasilkan dari benda tersebut.

Istilah “wakaf produktif”bisa dianggap kurang tepat jika melihat konsep wakaf itu sendiri yang sebenarnyaadalah pengelolaan secara produktif suatu aset yang manfaatnya digunakan untuktujuan sosial dan kedermawanan. Konsep ini terlihat pada definisi wakaf dalamkitab-kitab fikih dan juga dalam praktik. Misalnya, pada masa Nabi Muhammad, adawakaf kebun di Khaibar milik Umar yang hasil dari kebun tersebut diberikan untuksedekah kepada masyarakat miskin dan termasuk untuk membebaskan budak. ${ }^{11}$ DiMesir pada masa Mamluk, banyak wakaf aset komersial, seperti rumah, pertanian,peternakan, dan budak, yang keuntungannya untuk sedekah sosial, termasuk untuk operasional lembaga pendidikan dan gaji guru di Mesir, bahkan untuk menyediakankiswah Ka'bah, dan mengurus jenazah di Mekkah dan Madinah. $^{12}$ Walau dalampraktiknya ada wakaf yang berupa aset bisnis komersial dan

\footnotetext{
${ }^{11}$ Sahih Muslim, Hadis No. 4006

${ }^{12}$ Amelia Fauzia, Faith and the State: A History of Islamic Philanthropy in Indonesia, Disertasi, (Melbourne: Melbourne University, 2008), h. 52
}

ada pula berupa asetfasilitas umum $^{13}$, bisa dikatakan bahwa konsep wakaf itu sendiri memang sudah memiliki implikasi produktif. Istilah "wakaf produktif" harus dilihat dalam konteks usahapengarusutamaan (mainstreaming) pengelolaan wakaf ke arah yang produktif. DiIndonesia bentuk wakaf produktif yang cukup konvensional dan dipraktikkansebelum masa Kolonial Belanda adalah wakaf tanah sawah yang hasilkeuntungannya untuk membiayai operasional masjid dan untuk tujuan sosial lain. $^{14}$

\subsection{Wakaf Tunai}

Wakaf tunai disebut juga dengan wakaf uang. Majelis Ulama Indonesia (MUI) telah menetapkan fatwa tentang wakaf uang yang isinya sebagai berikut: ${ }^{15}$

a) Wakaf uang (cash waqf atau waqf alnuqud) adalah wakaf yang dilakukan seseorang, kelompok orang, lembaga, atau badan hukum dalam bentuk uang tunai.

b) Termasuk ke dalam pengertian uang adalah surat-surat berharga.

c) Wakaf uang hukumnya jawaz (boleh).

\footnotetext{
${ }^{13}$ Doris Behrens-Abouseif, Egypt's Adjustment to Ottoman Rule Institution, Waqf and Architecture in Cairo (16th and 17th Centuries), (Leiden: EJ Brill, 1994), h. 90

${ }^{14}$ Amelia Fauzia, Op.Cit., h. 105

${ }^{15}$ Fatwa Majelis Ulama Indonesia tentang Wakaf Uang, 11 Mei 2002
} 
d) Nilai pokok wakaf uang dijamin kelestariannya, tidak boleh dijual, dihibahkan, dan/atau diwariskan.

Undang-undang Wakaf Nomor 41 Tahun 2004 menyatakan bahwa uang merupakan salah satu bentuk benda wakaf bergerak. ${ }^{16}$

Jumlah umat Islam yang terbesar di dunia terutama di Indonesia merupakan aset terbesar untuk penghimpunan dan pengembangan wakaf uang. Jika wakaf uang dapat diimplementasikan, maka akan terdapat dana potensial yang dapat dipergunakan bagi kemaslahatan umat. Berdasarkan asumsi Cholil Nafis ${ }^{17}$, jika 20 juta umat Islam Indonesia mau mengumpulkan wakaf uang senilai Rp100 ribu setiap bulan, maka dana yang terkumpul berjumlah Rp24 triliun setiap tahun. Jika 50 juta orang yang berwakaf, maka setiap tahun akan terkumpul dana wakaf sebesar Rp60 triliun. Jika 1 juta orang yang berwakaf, maka dana yang akan terkumpul berjumlah Rp100 miliar setiap bulan dan Rp1,2 triliun per tahun.

Menurut Mustafa Edwin Nasution ${ }^{18}$, jumlah umat Islam yang dermawan diperkirakan sebesar 10 juta jiwa dengan rata-rata

\footnotetext{
${ }^{16}$ Pasal 16 ayat 1-3 Undang-undang Nomor 41 Tahun 2004 tentang Wakaf

${ }^{17}$ Cholis Nafis, Wakaf Uang untuk Jaminan Sosial, Jurnal Al-Awqaf, Vol. II, Nomor 2, April 2009

${ }^{18}$ Mustafa Edwin Nasution dan Uswatun Hasanah (ed), Wakaf Tunai: Inovasi Finansial Islam (Jakarta: PSTTI UI, 2006), h. 43-44
}

penghasilan Rp500 ribu hingga Rp10 juta, maka paling tidak akan terkumpul dana sekitar 3 triliun per tahun dari wakaf uang sebagaimana terlihat pada tabel berikut.

Tabel 1. Potensi wakaf uang

\begin{tabular}{|c|c|c|c|c|}
\hline $\begin{array}{c}\text { Tingkat } \\
\text { penghasilan/bulan }\end{array}$ & $\begin{array}{c}\text { Jumlah } \\
\text { Muslim }\end{array}$ & $\begin{array}{c}\text { Besar } \\
\text { wakaf/bulan }\end{array}$ & $\begin{array}{c}\text { Potensi wakaf } \\
\text { uang/bulan }\end{array}$ & $\begin{array}{c}\text { Potensi wakaf } \\
\text { uang/tahun }\end{array}$ \\
\hline Rp500 ribu & 4 juta & Rp5.000 & Rp20 miliar & Rp240 miliar \\
\hline Rp1 juta - Rp2 juta & 3 juta & Rp10.000 & Rp30 miliar & Rp360 miliar \\
\hline Rp2 juta - Rp5 juta & 2 juta & Rp50.000 & Rp100 miliar & Rp1.2 triliun \\
\hline >Rp5 juta & 1 juta & Rp100.000 & Rp100 miliar & Rp1.2 triliun \\
\hline
\end{tabular}

Sumber: Nasution dan Hasanah ${ }^{19}$

Berdasarkan Undang-undang Nomor 41 Tahun 2004, penerimaan dan pengelolaan wakaf uang dapat diintegrasikan dengan lembaga keuangan syariah. Dalam wakaf uang, wakif dapat mewakafkan benda bergerak berupa uang melalui lembaga keuangan syariah yang ditunjuk oleh menteri. ${ }^{20}$ Menteri Agama menunjuk lima bank syariah untuk bermitra dengan nazir dalam wakaf uang, yaitu Bank Muamalat Indonesia, Bank Syariah Mandiri, BNI Syariah, Bank DKI Syariah, dan Bank Mega Syariah. ${ }^{21}$ Kelima bank tersebut disebut dengan lembaga keuangan syariah penerima wakaf uang (LKS PWU).

\footnotetext{
${ }^{19}$ Mustafa Edwin Nasution dan Uswatun Hasanah (ed), Wakaf Tunai: Inovasi Finansial Islam (Jakarta: PSTTI UI, 2006), h. 43-44

${ }^{20}$ Pasal 28 Undang-undang Nomor 41 Tahun 2004 tentang Wakaf

${ }^{21}$ Keputusan Menteri Agama Republik Indonesia Nomor 92-96 Tahun 2008
} 


\subsection{Manajemen Keuangan}

Manajemen berasal dari Bahasa Latin, yaitu dari asal kata manus yang berarti tangan dan agere yang berarti melakukan. Kata-kata itu digabung menjadi kata managere yang artinya menangani. Kata managere diterjemahkan ke dalam Bahasa Inggris menjadi kata kerja to manage, kata benda management, dan manager untuk orang yang melakukan kegiatan manajemen atau pengelolaan. ${ }^{22}$

Henry M. Botiger mengemukakan manajemen sebagai suatu seni membutuhkan tiga unsur, yaitu pandangan, pengetahuan teknis, dan komunikasi. ${ }^{23}$ Menurut Menry Parker Follet mengemukakan definisi manajemen sebagai "the art of getting things done through people", artinya seni melaksanakan pekerjaan melalui orangorang. ${ }^{24}$

Manajemen adalah suatu proses sosial yang berkenaan dengan keseluruhan usaha manusia dengan bantuan manusia lain serta sumber-sumber lainnya, menggunakan metode yang efisien dan efektif untuk mencapai tujuan yang ditentukan sebelumnya. ${ }^{25}$ Menurut Terry dan Franklin,

\footnotetext{
${ }^{22}$ Husaini Usman, Manajemen: Teori, Praktik, dan Riset Pendidikan, (Jakarta: Bumi Aksara, 2009), h. 5

${ }^{23}$ Nanang Fattah, Landasan Manajemen Pendidikan, (Bandung: PT Remaja Rosdakarya, 2011), h. 3

${ }^{24}$ Husaini Usman, Op.Cit., h. 3

${ }^{25}$ Oemar Hamalik, Manajemen Pengembangan Kurikulum, (Bandung: PT Remaja Rosdakarya, 2006), h. 16-17
}

manajemen adalah "management is the process of designing and maintaining an environment in which individuals, working together in groups, efficiently accomplish selected aims", artinya proses merancang dan memelihara suatu lingkungan di mana individu-individu, bekerjasama dalam kelompok, secara efisien mencapai tujuan yang dipilih. ${ }^{26}$

Sementara itu, manajemen keuangan merupakan manajemen terhadap fungsi keuangan. Fungsi keuangan tersebut meliputi bagaimanamemperoleh dana (raising of fund) dan bagaimana menggunakan danatersebut (allocation of fund). ${ }^{27}$ Manajemen keuangan secara sederhana bisa diartikan sebagai suatu proses melakukan kegiatan mengatur keuangan dengan menggerakkan tenaga orang lain, dengan mempertimbangkan aspek efektivitas dan efisiensi yang berkaitan dengan perolehan, pendanaan, dan pengelolaan aktiva dengan beberapa tujuan menyeluruh yang dimulai dari perencanaan, pengorganisasian, pelaksanaan, sampai dengan pengawasan. ${ }^{28}$

Keuangan itu sendiri merupakan seni dan ilmu mengelola uang, yaitu aktivitas untuk memperoleh sumber capital(modal)

\footnotetext{
${ }^{26}$ Jejen Musfah, Manajemen Pendidikan: Teori, Kebijakan, dan Praktik, (Jakarta: Prenadamedia Group, 2015), h. 2

${ }^{27}$ Abubakar dan Taufani Chusnul Kurniatun, Manajemen Keuangan, (Jakarta: Nusantara Consulting, 2009), h. 2

${ }^{28}$ Sri Minarti, Manajemen Sekolah, (Yogyakarta: ArRuzz Media, 2011), h. 213
} 
dengan biaya yang semurah-murahnya dan menggunakannya seefektif dan seefisien mungkin. Penggunaan capital itu harus menghasilkan hasil (return, benefit) yang lebih besar dari biayanya. ${ }^{29}$

\subsection{Sejarah Singkat Alkhairaat}

Pada umumnya berdirinya sebuah organisasi tentu dikarenakan oleh berbagai faktor. Begitu pun dengan berdirinya organisasi Islam Alkhairaat, juga diakibatkan oleh beberapa faktor. Beberapa faktor yang melatarbelakangi berdirinya Alkhairaat, yaitu pertama, faktor kebodohan karena ketertinggalan dalam hal pendidikan. Saat itu, masyarakat Palu mengalami tekanan dari pihak Kolonial Belanda. Meskipun pemerintah Kolonial Belanda menyediakan sarana pendidikan, namun terbatas hanya untuk kalangan Kristen. Kedua, mayoritas penduduk Lembah Palu memeluk agama Islam dan belum ada sekolah yang berasaskan Islam. Ketiga, para mubalig masih kurang, terutama untuk memenuhi kebutuhan dalam memberikan ceramah dan dakwah. Keempat, saat itu umat Islam masih hidup menganutsistem kepercayaan yang bersifat sinkretisme. ${ }^{30}$ Latar belakang kondisi masyarakat Islam Lembah Palu tersebut telah memotivasi Sayyid Idrus bin

\footnotetext{
${ }^{29}$ Darsono, Manajemen Keuangan, (Jakarta: Nusantara Consulting, 2009), h. 2

${ }^{30}$ Sofjan B. Kambay, Perguruan Islam Alkhairaat dari Masa ke Masa, (Palu: Tim Peneliti S.K.P.B Alkhairaat, 1991), h. 18
}

Salim Aljufri (Guru Tua) untuk melakukan sesuatu bagi masyarakat Palu. Hal itu diwujudkan melalui organisasi Islam Alkhairaat.

Penggunaan nama Alkhairaat tidak bisa dilepaskan dari nama lembaga pendidikan yang pernah berdiri di Hadramaut, namun bukan tanpa alasan dan tanpa makna ketika Sayyid Idrus tetap menggunakan nama monumental tersebut. Dasar penamaan Alkhairaat adalah kata khairat di dalam sembilan ayat Quran, yaitu al-Baqarah: 148, Ali Imran: 114, al-Maidah: 48, al-Anbiya: 73 dan 90, al-Mu'minin: 56 dan 61, dan Fathir: 32, plus "al" sebagai atribut yang menunjukkan bahwa apa yang disebut itu tergambar dalam pikiran sebagaimana adanya. ${ }^{31}$

Sejarah mencatat bahwa Sayyid Idrus telah melakukan perjalanan ke Indonesia sebanyak dua kali. Kedatangannya pertama kali bersama ayahnya, Sayyid Salim Aljufri, pada tahun $1296 \mathrm{H} / 1878$. Ketika itu, ia berusia 17 tahun. Kedatangannya yang pertama ini adalah untuk mengunjungi keluarga di Jawa dan Sulawesi. Sementara itu, kedatangan Sayyid Idrus kedua kalinya adalah pada tahun $1922 .{ }^{32}$

\footnotetext{
${ }^{31}$ Abdul Wahab Abdul Muhaimin, Kata Pengantar dalam Sayyid Idrus bin Salim Aljufri: Pendiri Alkhairaat dan Kontribusinya dalam Pembinaan Umat, (Jakarta: Gaung Persada Press, 2014), hal. xii

${ }^{32}$ Huzaemah T. Yangko, Sayyid Idrus bin Salim Aljufri: Pendiri Alkhairaat dan Kontribusinya
} 
Sayyid Idrus tiba di Wani, Donggala pada tahun 1929 atau awal tahun 1930. Awalnya ia ingin mendirikan madrasah di Wani, tetapi ia berubah pikiran untuk pindah ke Palu. Keinginannya untuk pindah ke Palu mendapat sambutan baik dari Magau Ijazah (raja Palu) dan mendapat izin dari Pemerintah Hindia Belanda. Atas persetujuan semua pihak, termasuk restu Sayyid Muhammad al-Rifa'i, proses pendirian madrasah dipindahkan ke Palu. ${ }^{33}$ Setelah pindah ke Palu pada tanggal 30 Juli 1930 atau bertepatan 14 Muharram $1349 \mathrm{H}$, Madrasah Islamiyah Alkhairaat dibuka secara resmi. ${ }^{34}$

Sejak resmi berdiri, Alkhairaat terus berkembang. Awalnya hanya sebuah madrasah namun kemudian berkembang menjadi sebuah organisasi keagamaan yang berdiri sendiri. Tidak dapat dipungkiri dalam sejarah perkembangannya, kerap mengalami berbagai tantangan. Tantangan tersebut secara khusus berasal dari Pemerintah Kolonial Belanda maupun Jepang yang saat itu sedang berkuasa di Sulawesi Tengah, secara kusus di Lembah Palu. Baik Belanda maupun Jepang selalu mengawasi aktivitas dakwah dan proses belajar-mengajar di

dalam Pembinaan Umat, (Jakarta: Gaung

Persada Press, 2014), h. 22

${ }^{33}$ Gani Jumat, Nasionalisme Ulama: Pemikiran Politik Kebangsaan Sayyid Idrus bin Salim Aljufri, Disertasi, (Jakarta: UIN Syarif Hidayatullah, 2012), h. 73-74

${ }^{34}$ Sofjan B. Kambay, Op.Cit., h. 2
Pesantren Alkhairaat. Secara khusus pada masa kekuasaan Jepang, sejarah mencatat bahwa Sayyid Idrus dan Alkhairaat menjadi pusat kecurigaan Jepang. Saat itu, pejabat Jepang yang berkuasa di Palu mengeluarkan perintah untuk menghentikan dakwah Alkhairaat dan aktivitas pendidikannya. Dengan begitu, mereka bisa menggunakan gedung Alkhairaat sebagai pusat tentara Jepang. Dilaporkan bahwa saat itu beberapa murid Sayyid Idrus yang menghalangi tentara Jepang ditangkap dan dipenjarakan. ${ }^{35}$

Namun dengan berbagai tantangan tersebut, Alkhairaat tetap mampu berdiri hingga menjadi sebuah organisasi Islam terbesar di Wilayah Indonesia Bagian Timur, bahkan hingga kini jaringan Alkhairaat juga telah masuk ke Wilayah Indonesia Bagian Tengah dan Barat.

\section{METODE PENELITIAN}

Penelitian ini dilakukan di Kantor Pengurus Besar Alkhairaat pada bulan Februari 2019.Penelitian ini menggunakan data primer dan data sekunder. Data primer adalah data yang diperoleh langsung dari tempat penelitian berupa hasil wawancara dan observasi, sedangkan data sekunder adalah data yang sudah diolah oleh sumber data. Adapun sumber datanya adalah Pengurus Besar Alkhairaat.

\footnotetext{
${ }^{35}$ Gani Jumat, Op Cit., h. 168
} 
Metode pengumpulan data yang digunakan adalah metode pengumpulan data secara langsung dari tempat penelitian, yaitu dengan cara mendatangi Kantor Pengurus Besar Alkhairaat secara langsung untuk mengumpulkan data yang dibutuhkan dari sumber data.

Jenis penelitian yang digunakan adalah penelitian kualitatif dan penelitian kuantitatif. Penelitian kualitatif adalah metode penelitian yang lebih menekankan pada aspek pemahaman secara mendalam terhadap suatu masalah daripada melihat permasalahan untuk generalisasi. ${ }^{36}$ Sementara itu,penelitian kuantitatif adalah penelitian yang menggunakan data berupa angka-angka, mulai dari pengumpulan data, penafsiran terhadap data, hingga penampilan dari hasilnya. ${ }^{37}$

Metode analisis yang digunakan pada penelitian ini adalah (a) metode deskripsi untuk menggambarkan manajemen keuangan pada objek penelitian; dan (b) metode analisis tabel untuk menghitung tingkat efisiensi pengelolaan dana wakaf dilihat dari sisi pengeluaran. Formula perhitungannya adalah rasio antara penerimaan dana wakaf dan belanja rutin, di mana semakin kecil

\footnotetext{
${ }^{36}$ Uki Erlistina, Penelitian Kuantitatif dan Kualitatif,(Online: https://afidburhanuddin.wordpress.com/ 2013/05/21/penelitian-kuantitatif-dankualitatif/),diakses pada 23 Februari 2019, ${ }^{37}$ Ibid.
}

rasionya maka semakin efisien pengelolaan dana wakaf.

\section{HASIL DAN PEMBAHASAN}

4.1 Pengelolaan Dana Wakaf oleh Pengurus Besar Alkhairaat di Kota Palu

Pengurus Besar Alkhairaat tidak memiliki sebuah lembaga wakaf tersendiri yang khusus mengelola dana wakaf. Namun demikian, meskipun tidak memiliki lembaga khusus yang mengelola wakaf, Pengurus Besar Alkhairaat memiliki beberapa rekening bank yang digunakan untuk menerima dan menyimpan dana wakaf, baik dana hasil usaha wakaf produktif maupun wakaf tunai.Pengurus Besar Alkhairaat bekerjasama dengan beberapa bank, yaitu Bank Muamalat dengan nomor rekening 83220002025, BNI Syariah dengan nomor 0705050701, dan Bank Mandiri dengan nomor $1510099020908 .{ }^{38}$

\section{Pengurus Besar Alkhairaat}

memperoleh dana wakaf dari usaha-usaha wakaf produktif yang dimilikinya, yaitu swalayan Alkhairaat, penyewaan rumah toko, Rumah Sakit Umum SIS Aljufri, Gedung Al-Muhsinin, dan kebun kelapa. Usaha-usaha wakaf produktif tersebut secara aktif memberikan pemasukan dana wakaf setiap bulan atau setiap tahun ke Pengurus

\footnotetext{
${ }^{38}$ Data primer berupa hasil wawancara dengan narasumber di tempat penelitian
} 
Besar Alkhairaat. Wakaf-wakaf produktif tersebut diperoleh dari para pemberi wakaf,seperti Ketua Utama Pengurus Besar Alkhairaat Sayyid Saggaf Aljufri, Kementerian Agama, dan lain-lain. ${ }^{39}$

Estimasi penerimaan dana wakaf dari beberapa unit usaha wakaf produktif,yaitudari swalayan Alkhairaat sebesar Rp20-30 juta per bulan, dari 5 unit usaha penyewaan rumah toko sebesar Rp3540 juta per rumah toko per tahun, dari Rumah Sakit Umum SIS Aljufri sebesar Rp20 juta per bulan, dari Gedung AlMuhsinin sebesar Rp35-40 juta per bulan, dan dari kebun kelapa dengan hasil yang sangat relatif. ${ }^{40}$

Selain menerima dana wakaf dari usaha-usaha wakaf produktif, Pengurus Besar Alkhairaat juga menerima pemasukan wakaf tunai dari program khusus untuk menggalang dana dari masyarakat, yaitu Kemandirian Ekonomi Khusus Alkhairaat (Kekal), yang menghimpun dana melalui dua pintu, yakni Gerakan Cinta Alkhairaat (Genta) dan layanan langganan pesan singkat yang berisi tausiah dari pendiri Alkhairaat, Habib Idrus bin Salim Aljufri atau Sayyid Idrus. $^{41}$
Dana wakaf yang diterima oleh Pengurus Besar Alkhairaat dialokasikan 50\% untuk gaji guru honorer dan guru PNS yang memiliki jam ajar melebihi jam ajar yang ditetapkan, dan sisanya dialokasikan untuk biaya perjalanan pengurus Pengurus Besar Alkhairaat ke luar daerah untuk keperluankeperluan tertentu dan administrasi. ${ }^{42}$

Jumlah sekolah/madrasah yang dikelola dengan dana wakaf oleh Pengurus Besar Alkhairaat kurang lebih sebanyak 1.600 sekolah/madrasah di Indonesia Bagian Timur. Alkhairaat memiliki tujuh macam lembaga pendidikan, yaitu pendidikan anak usia dini (PAUD), sekolah dasar (SD), sekolah menengah pertama (SMP), sekolah menengah atas (SMA), dan sekolah menengah kejuruan (SMK), madrasah ibtidaiyah (MI), madrasah tsanawiyah (MTs), dan madrasah aliyah (MA). ${ }^{43}$

Jumlah sekolah/madrasah yang dikelola dengan dana wakaf oleh Pengurus Besar Alkhairaat di Kota Palu berjumlah 5 sekolah/madrasah, yaitu TK Alkhairaat Palu dengan jumlah pendidik dan tenaga kependidikan (PTK) sebanyak 22 orang, MI Alkhairaat Palu dengan jumlah PTK sebanyak 8 orang, MA Alkhairaat Palu sebanyak 46 orang, SMA Alkhairaat Palu

\footnotetext{
${ }^{39}$ Data primer berupa hasil wawancara dengan narasumber di tempat penelitian

${ }^{40}$ Data primer berupa hasil wawancara dengan narasumber di tempat penelitian

${ }^{41}$ Data primer berupa hasil wawancara dengan narasumber di tempat penelitian
} 
sebanyak 25 orang, dan SMK Alkhairaat Palu sebanyak 31 orang. ${ }^{44}$

Penerimaan dan pengeluaran dana wakaf dibukukan secara berkala per bulan dan per tahun oleh Bendahara Pengurus Besar Alkhairaat dengan berkoordinasi kepada Ketua Umum Pengurus Besar Alkhairaat. Laporan bulanan dan tahunan tersebut akan dipertanggungjawabkan kepada Muktamar Alkhairaat yang diselenggarakan setiap lima tahun sekali. ${ }^{45}$

Pengelolaan dana wakaf oleh Pengurus Besar Alkhairaat belum melibatkan semua fungsi manajemen keuangan dengan baik. Fungsi manajemen yang tidak mendapatkan perhatian adalah perencanaan anggaran (budgeting) padahal fungsi tersebut merupakan tahapan terpenting dari semua fungsi manajemen untuk menghadapi lingkungan eksternal yang berubah-ubah secara dinamis.

\subsection{Efisiensi Pengelolaan Dana Wakaf oleh}

Pengurus Besar Alkhairaat di Kota Palu

Analisis efisiensi melihat rasio perbandingan antara output daninput atau pengeluaran dengan penerimaandana wakaf. Semakin kecil rasio ini maka semakin efisien, begitujuga sebaliknya. Efisiensi lebih menitikberatkan pada kemampuan suatu organisasi untukmencapai tujuan yang diharapkan dengan penggunaan sumberdaya yang lebih hemat.

Tabel 2. Tingkat efisiensi pengelolaan danawakat

\begin{tabular}{|c|c|c|c|c|}
\hline Bulan & Penerimaan & Pengeluaran & Efisiensi & Kriteria \\
\hline Januari & Rp172.470.800,00 & Rp130.598.950,00 & $76 \%$ & Efisien \\
\hline Februari & Rp173.168.000,00 & Rp137.166.300,00 & $79 \%$ & Efisien \\
\hline Maret & Rp161.888.000,00 & Rp272.658.800,00 & $168 \%$ & Tidak efisien \\
\hline April & Rp147.543.000,00 & Rp125.132.700,00 & $85 \%$ & Cukup efisien \\
\hline Mei & Rp149.128.000,00 & Rp151.875.200,00 & $102 \%$ & Tidak efisien \\
\hline Juni & Rp137.450.000,00 & Rp174.932.500,00 & $127 \%$ & Tidak efisien \\
\hline Juli & Rp138.915.000,00 & Rp120.832.100,00 & $87 \%$ & Cukup efisien \\
\hline Agustus & Rp157.482.500,00 & Rp162.012.400,00 & $103 \%$ & Tidak efisien \\
\hline September & Rp98.938.000,00 & Rp121.915.400,00 & $123 \%$ & Tidak efisien \\
\hline Oktober & Rp79.750.000,00 & Rp87.188.000,00 & $109 \%$ & Tidak efisien \\
\hline November & Rp90.316.000,00 & Rp89.182.200,00 & $99 \%$ & Kurang efisien \\
\hline Desember & Rp157.907.000,00 & Rp127.912.400,00 & $81 \%$ & Cukup efisien \\
\hline Total & Rp1.664.956.300,00 & Rp1.701.406.950,00 & $102 \%$ & Tidak efisien \\
\hline Rata-rata & Rp138.746.358,33 & Rp141.783.912,50 & $102 \%$ & Tidak efisien \\
\hline
\end{tabular}

Tabel 2 diatas menunjukkanbahwa tingkat efisiensi pengelolaan dana wakaf oleh Pengurus Besar Alkhairaat pada tahun 2018 adalah $102 \%$, artinya pengelolaan dana wakaf tersebut belum efisien karena pengeluaran rata-rata per bulan (Rp138.746.358,33)lebih besar dari pemasukan rata-rata per bulan (Rp141.783.912,50). Ini menunjukkan bahwa Pengurus Besar Alkhairaat belum mampu menutupi seluruh kebutuhan finansialnya dengan dana wakaf, baik dana hasil wakaf dan wakaf tunai.

\footnotetext{
${ }^{44}$ Data sekunder yang diperoleh dari narasumber di tempat penelitian

${ }^{45}$ Data primer berupa hasil wawancara dengan narasumber di tempat penelitian
} 


\section{PENUTUP}

Berdasarkan hasil penelitian, maka dapat ditarik kesimpulan bahwa:

a) Pengelolaan dana wakaf oleh Pengurus Besar Alkhairaat belum menunjukkan sebuah manajemen yang sempurna, di mana masih ada fungsi manajemen yang belum diterapkan dengan baik, yaitu perencanaan anggaran (budgeting). Ini berpengaruh besar terhadap kurangnya efisiensi pengelolaan tersebut, di mana pengeluaran lebih besar dari penerimaan.

b) Tingkat efisiensi pengelolaan dana wakaf oleh Pengurus Besar Alkhairaat pada tahun 2018 adalah 102\%, artinya pengelolaan dana wakaf tersebut belum efisien karena pengeluaran rata-rata per bulan (Rp138.746.358,33)lebih besar dari pemasukan rata-rata per bulan (Rp141.783.912,50).

\section{Saran}

Berikut ini saran untuk pengelolaan dana wakaf yang lebih baik untuk Alkhairaat ke depan, yaitu:

a) Hendaknya Pengurus Besar Alkhairaatlebih memperhatikan fungsi perencanaan anggaran (budgeting) agar bisa memantau pengeluaran dana wakaf untuk mengefisienkan pengeluaran.

b) Hendaknya Pengurus Besar Alkhairaatlebih memaksimalkan fungsi pengawasan (controlling) terhadap usaha-usaha wakaf produktif sehingga bisa memaksimalkan penerimaan dana wakaf untuk menutupi kebutuhan pengeluaran.

\section{DAFTAR PUSTAKA}

Abdurrahman. 1994. Masalah Perwakafan Tanah Milik dan Kedudukan Tanah Wakaf di Negara Kita. Bandung: Citra Karya Bakti, 1994

Abouseif, DB. 1994. Egypt's Adjustment to Ottoman Rule Institution, Waqf and Architecture in Cairo (16th and 17th Centuries). Leiden: EJ Brill.

Abubakar dan Kurniatun, TC. 2009. Manajemen Keuangan. Jakarta: Nusantara Consulting.

Darsono. 2009. Manajemen Keuangan. Jakarta: Nusantara Consulting.

Erlistina, U. 2013.Penelitian Kuantitatif dan Kualitatif.Online:

https://afidburhanuddin.wordpress.com / 2013/05/21/penelitian-kuantitatifdan-kualitatif/. [Diakses pada 23 Februari 2019, pukul 14.21]

Fattah, N. 2011. Landasan Manajemen Pendidikan. Bandung: PT Remaja Rosdakarya.

Fauzia, A. 2008. Faith and the State: A History of Islamic Philanthropy in Indonesia, Disertasi. Melbourne: Melbourne University.

Hamalik, O. 2006. Manajemen Pengembangan Kurikulum. Bandung: PT Remaja Rosdakarya.

Jumat, G. 2012. Nasionalisme Ulama: Pemikiran Politik Kebangsaan Sayyid Idrus bin Salim Aljufri, Disertasi. Jakarta: UIN Syarif Hidayatullah. 
Kambay, SB. 1991. Perguruan Islam Alkhairaat dari Masa ke Masa. Palu: Tim Peneliti S.K.P.B Alkhairaat.

Minarti, S. 2011. Manajemen Sekolah. Yogyakarta: Ar-Ruzz Media.

Munawwir, A. W. 2002. Kamus AlMunawwir, Cet. Ke-25. Surabaya: Pustaka Progressif.

Musfah, J. 2015. Manajemen Pendidikan: Teori, Kebijakan, dan Praktik. Jakarta: Prenadamedia Group.

Nafis, C. 2009. Wakaf Uang untuk Jaminan Sosial.Jurnal Al-Awqaf, Vol. II, Nomor 2, April 2009.

Nasution, ME. 2006. Wakaf Tunai: Inovasi Finansial Islam. Jakarta: PSTTI UI.

Republik Indonesia. 2003. Undang-undang Nomor 20 Tahun 2003 Tentang Sistem
Pendidikan Nasional. Lembaran Negara Nomor 78 Tahun 2003.Jakarta: Sekretariat Negara.

Republik Indonesia. 2004. Undang-Undang Nomor 41 Tahun 2004 tentang Wakaf. Lembaran Negara Nomor 159 Tahun 2004. Jakarta: Sekretariat Negara.

Ridho, T. 2006. Panduan Wakaf Praktis. Jakarta: Tabung Wakaf Indonesia.

Usman, H. 2009. Manajemen: Teori, Praktik, dan Riset Pendidikan. Jakarta: Bumi Aksara.

Yangko, HT. 2014. Sayyid Idrus bin Salim Aljufri: Pendiri Alkhairaat dan Kontribusinya dalam Pembinaan Umat. Jakarta: Gaung Persada Press. 